\title{
Long-Term Stability Of Ethnocentric Consumer Attitudes
}

\author{
Martin Fraering, (E-mail: mf53@evansville.edu), University of Evansville
}

\begin{abstract}
This research conducts the first cohort longitudinal study of the CETSCALE. Data collected in surveys of Business Administration students in 2000, and the fall of 2005 and winter of 2006 are analyzed to determine whether the ethnocentric attitudes of consumers have changed. Nonnormal distribution of the data due to kurtosis and severe skewness complicate confirmatory factor analysis, necessitating a three-phased effort to obtain an acceptable construct. The results indicate that although the mean CETSCALE score decreased two points (from 45.2 to 43.2), the change was not significant at $p=0.05$. This research also confirms that the CETSCALE remains a highly reliable survey instrument, with Cronbach's Alpha of 0.94 and Composite Reliability of 0.93. Implications of this study for practitioners and the future study of consumer attitudes toward the purchase of imported products are also addressed.
\end{abstract}

\section{INTRODUCTION}

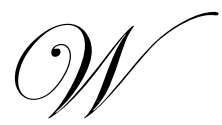

hen Dubai Ports World purchased a number of seaport terminals in the U.S. in the first quarter of 2006 from a British firm considerable controversy ensued. The ferocity of the ethnocentric sentiments directed toward the Arab-owned firm surprised international business scholars, and particularly international marketing experts (Kirchgaessner, Alden, Yeager, and Sevastopulo 2006). Objection to the acquisition was at odds with the record-breaking current account trade deficits between the United States and major trading partners such as China and the European Union ("US Trade Deficit Widens Further" 2006). Are these concerns voiced by American citizens and politicians a sign that Americans are turning inward? Is their love affair with inexpensive imported goods over?

The CETSCALE (Shimp and Sharma 1987) introduced the notion of consumer ethnocentrism as a measurable attitude in the United States. Mean CETSCALE scores were calculated to demonstrate differences in patriotic preferences for US-made products. Since then many other CETSCALE studies have been conducted around the world. Research has been conducted in Russia and the United States (Durvasula, Andrews, and Netemeyer 1997), Mexico (Bailey and Gutierrez de Pineres 1997), Japan, the United States, and Sweden (Hult, Keillor, and Lafferty 1999), New Zealand (Watson and Wright 2000), Spain (Luque-Martinez, Ibanez-Zapata, and Barrio-Garcia 2000), the Czech Republic, Hungary, and Poland (Lindquist et al. 2001), China, India, and Taiwan (Pereira, Hsu, and Kundu 2002), Turkey (Kaynak and Kara 2002), Israel (Shoham and Brencic 2003), and the United States, Slovenia, and Kazakhstan (Reardon et al. 2005). Longitudinal studies are very rare in both International Business and Marketing research, and there has been only one longitudinal CETSCALE study: Nielsen and Spence (1997) measured the stability of CETSCALE scores for eight weeks in the summer of 1992. To date there has not been any effort in any country to measure long term changes in ethnocentric attitudes. This effort fills that gap in our understanding of consumer biases against and in favor of foreign-made goods.

In the fall of 2005 and winter of 2006, 178 Business Administration students were surveyed to measure ethnocentric attitudes. The 2005-6 data are compared with that obtained in 2000 to determine differences (if any) in attitudes toward the purchase of foreign-made goods. This research will contribute to the international marketing literature in three ways. First, it will be the first CETSCALE study to measure the ethnocentric attitudes of different groups of Business Administration undergraduates five years apart (i.e., have well-educated young adults become more or less likely to purchase foreign-made goods?). Second, the current research verifies the reliability and validity 
of the CETSCALE. And the study will complement survey data being gathered regarding the growing controversy regarding legal and illegal immigration in the United States (Alden 2006; Alden and Johnson 2006; Johnson 2006).

\section{COMPARATIVE CETSCALE RESEARCH}

Considerable variance in CETSCALE scores has been observed between demographic groups. Shimp and Sharma (1987) found that mean scores varied by geographic region, with the Detroit area the most ethnocentric (mean score of 68.58) and Los Angeles the least ethnocentric (mean score of 56.62) of the four regions they surveyed. A recent study conducted in the Midwest United States (Yoo and Donthu 2005) noted that men (mean score of 44.45) were more ethnocentric in regard to Japanese-made products than women (mean score of 43.10), but not to a significant degree. And Bawa (2004) observed in India considerable differences from surveys of university students (mean score of 52.43), materials management professionals (mean score of 55.24), and high school seniors (mean score of 78.71).

Also noteworthy are the studies that compare ethnocentricity of consumers of various countries. A comparison of CETSCALE surveys conducted in India, Taiwan, and China obtained mean scores of 49.98, 56.1, and 57.97, respectively (Pereira, Hsu, and Kundu 2002). Durvasula and his colleagues (1997) found that Russians (mean score of 32.02) were considerably less ethnocentric than Americans (mean score of 50.24). Research conducted in the United States (Florida and Missouri), Japan, and Sweden by Hult, Keillor, and Lafferty (1999) observed relatively high ethnocentric attitudes in the US (mean score of 61.5), and relatively similar, more tolerant attitudes toward foreign-made goods in the latter two countries (means of 40.1 and 38.1, respectively). Another effort (Fraering and Elahee 2001) found South Texas college students fairly receptive to the purchase of foreign-made goods (mean score of 45.2), while their Mexican counterparts were considerably more ethnocentric (mean score of 61.2). Lastly, CETSCALE research in Eastern Europe conducted by Vida and Fairhurst (1999) has found considerable differences in the attitudes of consumers in Hungary (mean score of 43.30), the Czech Republic (mean score of 45.17), Poland (mean score of 50.61), and Estonia (mean score of 53.59).

Since the first CETSCALE research was published in 1987, observed ethnocentric attitudes in the US have trended downward. Mean scores of 56.62 to 68.58 obtained among the four regions surveyed by Shimp and Sharma (1987) were followed by 50.24 obtained by Durvasula, Andrews, and Netemeyer (1997). Shortly thereafter Hult, Keillor, and Lafferty (1999) reported a mean score of 61.5, a level commensurate with that found in the Carolinas study conducted by Shimp and Sharma (1987). Thereafter CETSCALE mean scores resumed their decline, reaching 45.2 (Fraering and Elahee 2001), and 43.87 (Yoo and Donthu 2005).

\section{Hypotheses}

Of the more than 17 published CETSCALE studies there has been only one longitudinal analysis of CETSCALE data, albeit for eight weeks (Nielsen and Spence 1997). This research is the first longitudinal study of the CETSCALE: Data from Fraering and Elahee (2001) is analyzed with surveys conducted in the fall of 2005 and winter of 2006 to determine the extent to which respondents are more or less ethnocentric in their consumption decisions.

It appears that the ethnocentric attitudes of consumers have declined since 1987, as lower means have been obtained since Shimp and Sharma (1987) by Durvasula, Andrews, and Netemeyer (1997), Fraering and Elahee (2001), and Yoo an Donthu (2005), respectively. Given the pattern of the results in the last twenty years, it is reasonable to expect that undergraduate students surveyed during the 2005-2006 school year are more willing to purchase foreignmade goods than those surveyed in 2000. Thus:

$\mathrm{H}_{1}$ : $\quad$ The strength of ethnocentric attitudes among consumers has declined since 2000

The veracity of $\mathrm{H}_{1}$ depends upon stability of the reliability of the CETSCALE as a measurement instrument. Prior CETSCALE research has reported Chronbach's Alphas from 0.96 (Shimp and Sharma 1987; Yoo and Donthu 2005) to 0.86 (Vida and Fairhurst 1997). However, most studies reviewed for this research obtained values of 0.90 or 
higher (e.g., Hult, Keillor, and Lafferty 1999; Kaynak and Kara 2002; Netemeyer, Durvasula, and Lichetenstein 1991; Shoham and Brencic 2003). Coefficients Alpha lower than 0.90 have been obtained in studies conducted by Vida and Fairhurst (1999) in the Czech Republic, Estonia, Hungary, and Poland (0.86), and by Periera, Hsu, and Kundu (2002) in Taiwan (0.89) and China (0.88). Values reported for U.S. samples have been between 0.94 and 0.96, the range reported by Shimp and Sharma (1987). Thus in this research:

\section{$\mathrm{H}_{2}$ : $\quad$ Scale reliability as measured by Cronbach's Alpha will be 0.90 or higher}

Similar to Coefficient Alpha is Composite Reliability, a measure typically used in structural equation modeling. Composite Reliability values of 0.97 to 0.88 (Durvasula, Andrews, and Netemeyer 1997) have been obtained. Values for U.S. samples have been between 0.97 (Durvasula, Andrews, and Netemeyer 1997) and 0.95 (Hult, Keillor, and Lafferty 1999; Netemeyer, Durvasula, and Lichtenstein 1991). These nearly identical results infer that:

$\mathrm{H}_{2 \mathrm{~b}}: \quad$ Construct reliability measured by Composite Reliability will be 0.90 or higher

In structural equation modeling the measure of the degree to which the observed variables share common variance to comprise the unobserved construct is the Variance Extracted. Thus the greater the Variance Extracted, the more the observed variables have in common with each other, and the more robust the construct. Although a minimum of 0.50 is recommended (Hair et al. 1995), a number of studies have reported lower values (Durvasula, Andrews, and Netemyer 1997; Hult, Keillor, and Lafferty 1999; Netemeyer, Durvasula, and Lichtenstein 1991; Periera, Hsu, and Kundu 2002). Values have been obtained for US samples between 0.64 (Durvasula, Andrews, and Netemeyer 1997) and 0.53 (Hult, Keillor, and Lafferty 1999). In this research:

$\mathrm{H}_{3}$ : $\quad$ Variance Extracted will be greater than 0.50

\section{METHODOLOGY}

\section{Sample}

Surveys of university students have played a vital role in assessing the internal (Shimp and Sharma 1987), and external (Middelstaedt, Hopkins, Raymond, and Duke 2004) validity of the CETSCALE from its conception to the present. They are deemed well-suited for research that seeks to understand perceptual or decision processes (Calder, Phillips, and Tybout 1981). Student samples are also recommended for cross-national tests of theory (Irvine and Carroll 1980), and when homogeneity is important (Douglas and Craig 1983; Douglas, Morris, and Craig 1994; Parameswaran and Yaprak 1987; Sekaran 1983). Among the research efforts conducted with surveys of students were studies in the US, West Germany, France, and Japan (Netemeyer, Durvasula, and Lichtenstein 1991), the U.S. and the Russian Republic (Durvasula, Andrews, and Netemeyer 1997), the US and Mexico (Fraering and Elahee 2001), as well as Taiwan, India, and China (Pereira, Hsu, and Kundu 2002).

To measure trends in consumer ethnocentric attitudes of Business Administration undergraduates a cohort ${ }^{1}$ longitudinal study (Babbie and Wagenaar 1992) was conducted. The first effort collected data from students at a South Texas university in 2000. The second study began in December of 2005 and concluded in January of 2006, surveying students in Indiana and Connecticut. A total of 279 questionnaires were obtained in the two surveys, with 270 respondents (96.8 percent) providing complete responses to the CETSCALE items (see Table 1). This very small portion of the questionnaires was not analyzed, as the number of complete survey forms was deemed adequate. Specifically, prior CETSCALE studies have employed samples of approximately the same size. These works include Durvasula, Andrews, and Netemeyer (1997), Herche (1992), Netemeyer, Durvasula, and Lichtenstein (1991), Sharma, Shimp, and Shin (1995), and Shimp and Sharma (1987). There was also a pattern of nonresponse to the demographics questions, with three individuals declining to answer items regarding age and gender, and 13 participants declining to specify their ethnicity. Two hundred seventeen ( 80.4 percent) of the respondents of the 2000 and 2005-6 surveys were between the ages of 18 and 24. Participation by gender was nearly an even split between men (49.6 percent) and women (49.3 percent). Participants in the two surveys represented a diverse mix of ethnicities, including Caucasians 
(58.2 percent), Hispanics (30.7 percent), Blacks (4.1 percent), and Asians (1.8 percent). The large number of Hispanics is due to the fact that they comprise a majority of the population of South Texas.

Table 1

Characteristics Of Sample

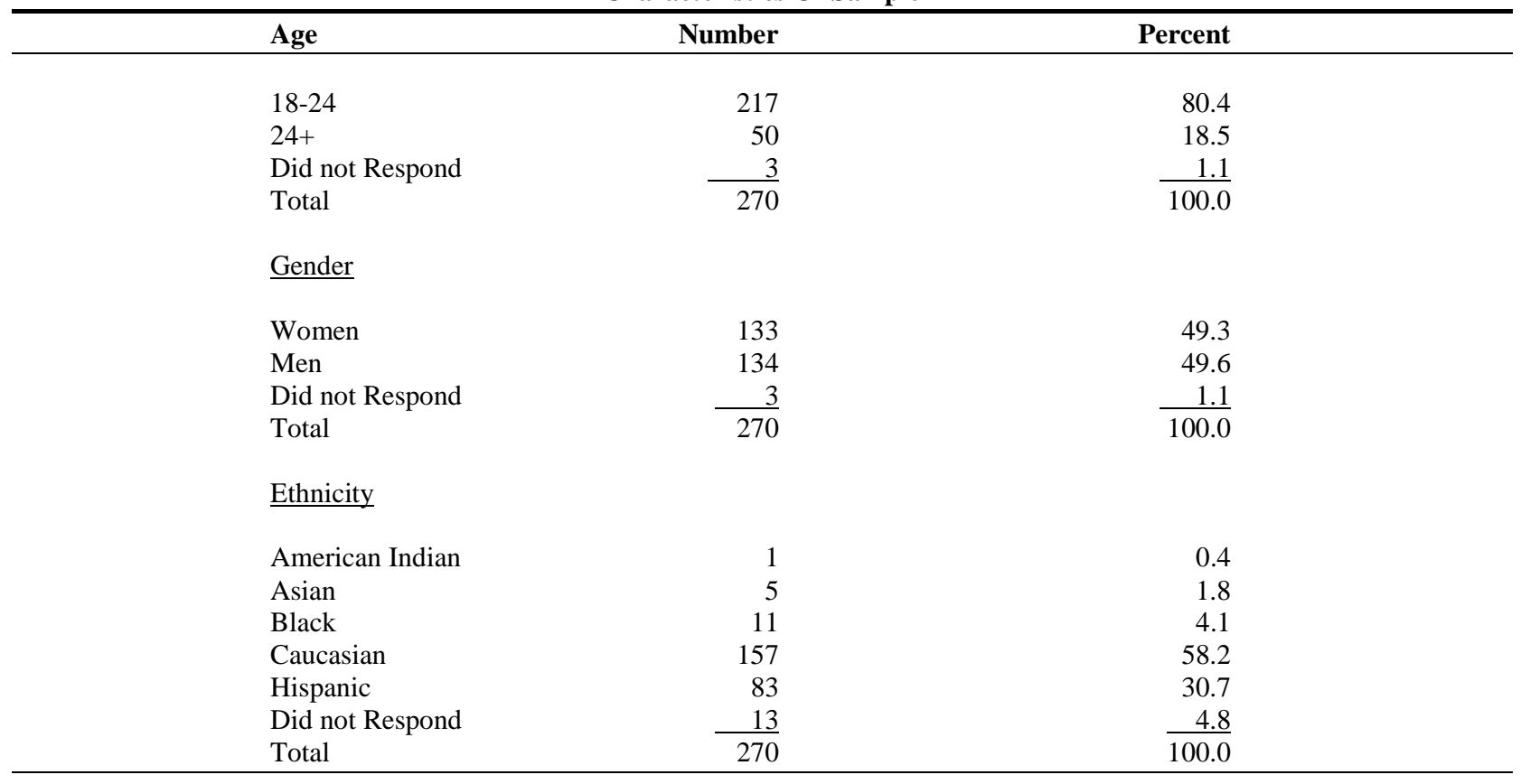

Table 2

Assessment Of Normality

\begin{tabular}{rrrrrrr}
\hline Item No. & Skewness & Z-Score & $\boldsymbol{p}$ & Kurtosis & Z-Score & $\boldsymbol{p}$ \\
\hline & & & & & -1.745 & $<0.040$ \\
2 & 0.587 & 3.935 & 0.000 & -0.520 & -.0927 & $<0.176$ \\
3 & 0.641 & 4.302 & 0.000 & -0.276 & -2.698 & $<0.004$ \\
4 & -0.052 & -0.349 & $<0.367$ & -0.804 & -1.746 & $<0.040$ \\
5 & 0.355 & 2.382 & $<0.009$ & -0.521 & 9.355 & 0.000 \\
6 & 1.595 & 10.700 & 0.000 & 2.789 & 0.123 & $<0.445$ \\
7 & 0.846 & 5.676 & 0.000 & 0.037 & 2.004 & $<0.023$ \\
8 & 1.122 & 7.527 & 0.000 & 0.597 & -0.705 & $<0.235$ \\
9 & 0.748 & 5.019 & 0.000 & -0.210 & -1.832 & $<0.034$ \\
10 & 0.528 & 3.541 & $<0.001$ & -0.546 & 0.366 & $<0.355$ \\
11 & 0.796 & 5.340 & 0.000 & 0.109 & -0.116 & $<0.455$ \\
12 & 0.766 & 5.141 & 0.000 & -0.035 & -0.236 & $<0.405$ \\
13 & 0.652 & 4.371 & 0.000 & -0.415 & -1.391 & $<0.083$ \\
14 & 0.459 & 3.082 & $<0.001$ & 1.363 & 4.572 & 0.000 \\
15 & 1.339 & 8.983 & 0.000 & 0.992 & 3.326 & $<0.001$ \\
16 & 1.191 & 7.987 & 0.000 & 0.099 & 0.333 & $<0.365$ \\
\hline
\end{tabular}




\section{Analysis Of The Data}

Casual inspection of the data indicates that the distributions for most of the CETSCALE items are positively skewed. This makes sense, given that mean CETSCALE scores have trended downward from a range between 68.58 and 56.62 (Shimp and Sharma 1987) to 50.24 (Durvasula, Andrews, and Netemeyer 1997), then 45.2 (Fraering and Elahee 2001), and most recently, 43.87 (Yoo and Donthu 2005). Thus on the seven-point scale for the 17 scale items most responses about 20 years ago were at or near the midpoint of the scale. Recently most responses are clustered around "two" and "three." Hence a formal normality assessment was conducted (See Table 2).

Using the statistical test for skew recommended by Hair and his colleagues (1995) it was determined that the data for 16 of the 17 scale items were significantly non-normal. The same test was conducted for kurtosis: It indicated that nine of the 17 CETSCALE items were significantly non-normal. Hence the suitability of the maximum likelihood method of model estimation for conducting confirmatory factor analysis is in doubt. The asymptotically distribution-free (ADF) method has traditionally been the preferred means of conducting confirmatory factor analysis with non-normal data (Bai 2003; Bentler 1983; Browne 1982; Browne 1984; Zheng et al. 2000). Similar results were obtained by Muthen (1989), who found that ADF was preferable to the generalized least squares (GLS) method. Additional support in favor of the use of ADF instead of GLS was asserted by Sharma and his colleagues (1989). However tests performed by Chan, Yung, and Bentler (1995) concluded that the performance of the ADF method was unsatisfactory. Furthermore they reported that the ADF method inflated the Type II error rate. Fouladi (2000) found that among the covariance structure analysis procedures available with most structural equation analysis software programs, GLS performed better than the maximum likelihood (ML) and ADF methods in processing non-normal data. In a comparison of the ML, GLS, and weighted least squares (WLS) methods Olsson and his colleagues (2000) determined that WLS is best suited to analyze large samples with data characterized by non-normal kurtosis. Their finding was partially supported by Lei and Lomax (2005), who found that there was no practical difference between ML and GLS in analyzing non-normal data with both skew and kurtosis. Hence there is a lack of consensus in the literature regarding the most suitable model estimation method to use in conducting confirmatory factor analysis when the data is non-normal due to skew and kurtosis.

\section{Model Estimation}

The structural equation modeling software available for this analysis is Amos 4.0 (Arbuckle and Wothke 1999). Amos provides three estimation methods for normally distributed data: ML, GLS, and unweighted least squares (ULS). The estimation method provided for data that is non-normally distributed is Browne's asymptotically distribution-free criterion (ADF). Given the lack of access to the WLS method and the findings of Lei and Lomax (2005), the first step was to attempt to conduct confirmatory factor analysis with the ML method. As predicted by Fouladi (2000), model fit was extremely poor: Excessive error variances (greater than 0.99) were obtained for observed variables one through four, nine, 12, 13, 15, and 16 (see Figure 1). These so-called Heywood cases may have been due to the non-normal distribution of the data, and/or due to the nature of the ML method (Kline 2005). This model is unacceptable for a construct that has been tested in the US at least five times (Durvasula, Andrews, and Netemeyer 1997; Fraering and Elahee 2001; Hult, Keillor, and Lafferty 1999; Shimp and Sharma 1987; Yoo and Donthu 2005), and in at least 18 foreign countries (Bawa 2004; Durvasula, Andrews, and Netemeyer 1997; Fraering and Elahee 2001; Good and Huddleston 1995; Hult, Keillor, and Lafferty 1999; Kaynak and Kara 2002; Netemeyer, Durvasula, and Lichtenstein 1991; Pereira, Hsu, and Kundu 2002; Sharma, Shimp, and Shin 1995; Shoham and Brencic 2003; Vida and Fairhurst 1999; Watson and Wright 2000). 


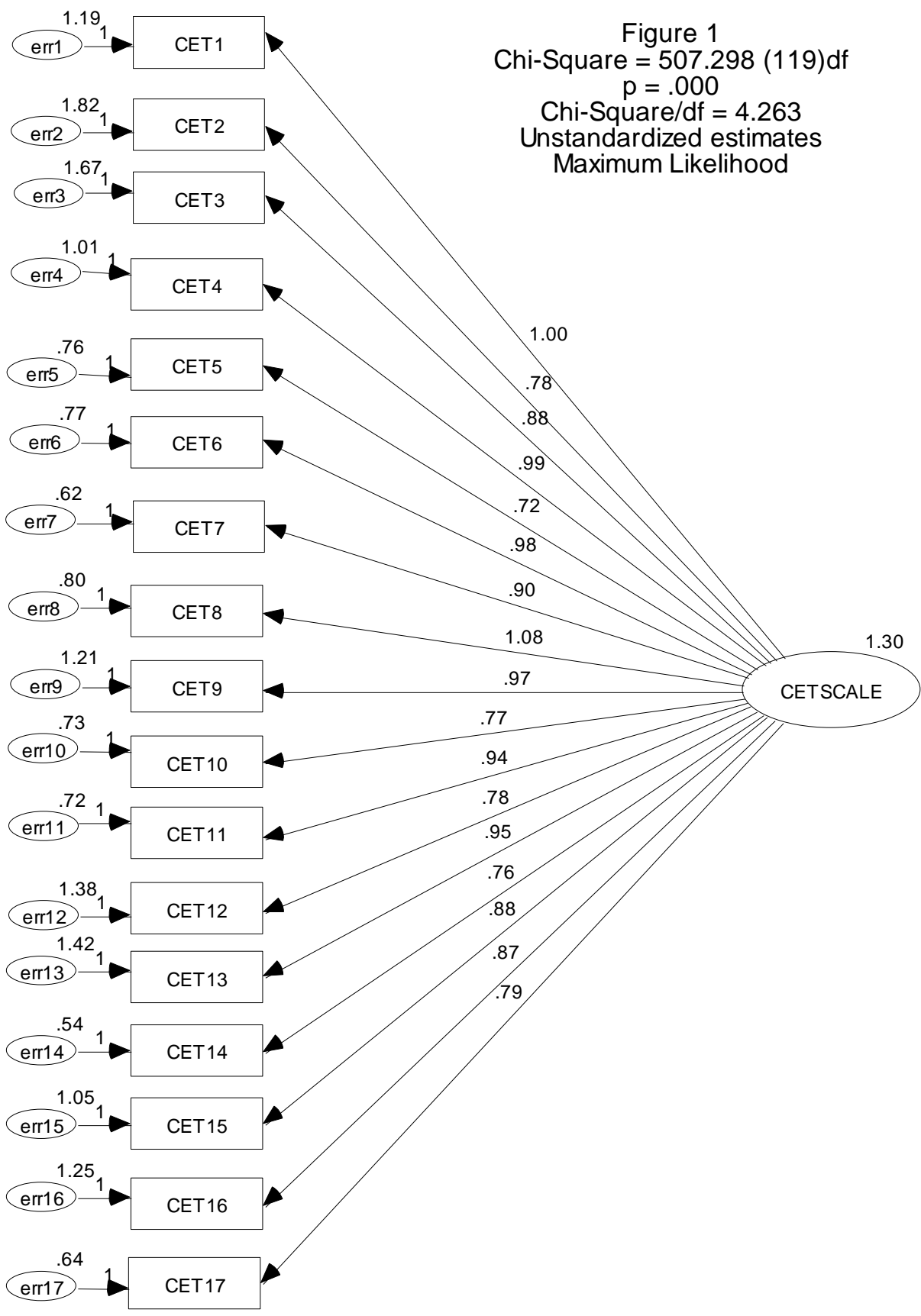




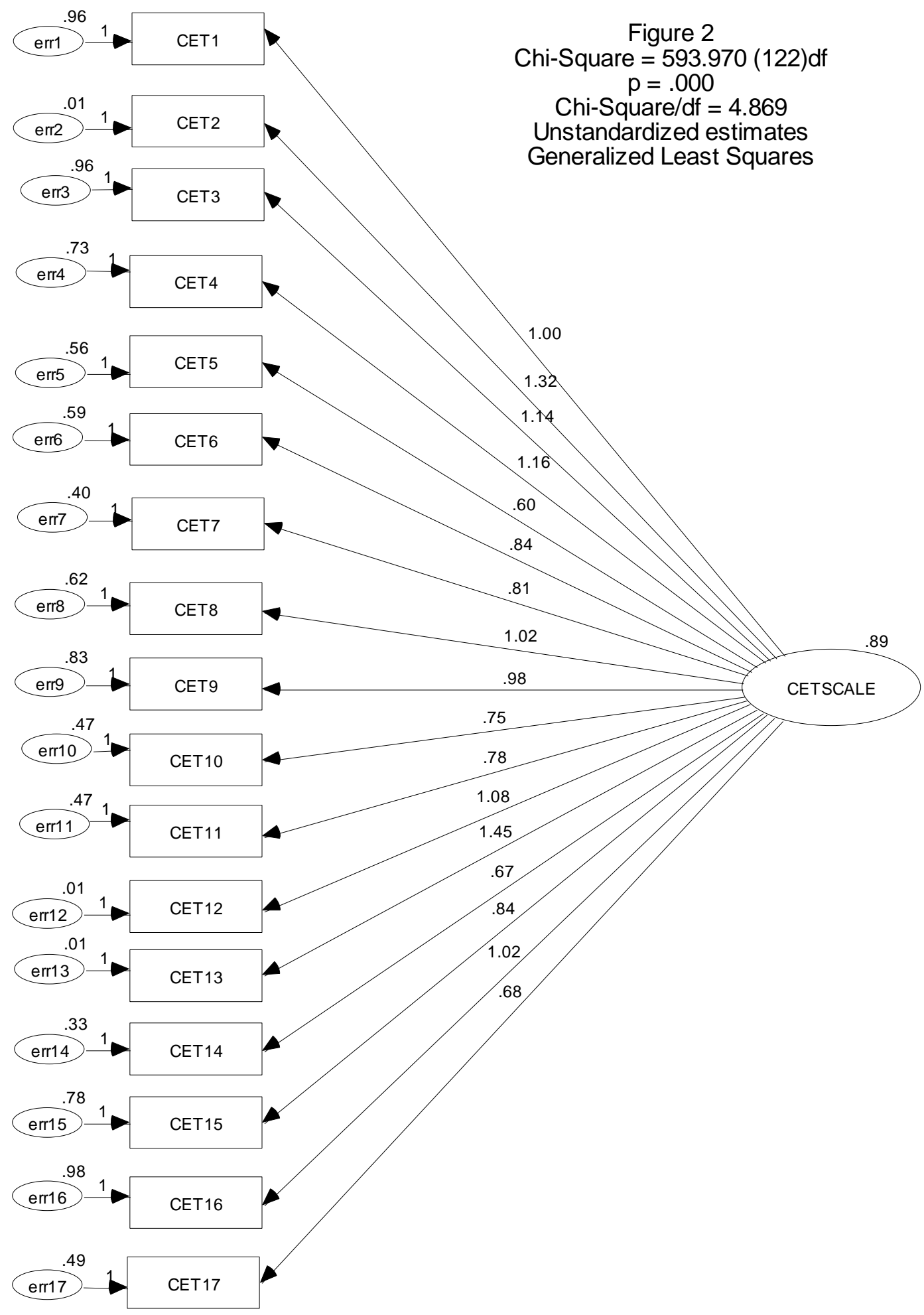


Owing to recommendations of the more recent literature (Fouladi 2000; Lei and Lomax 2005) the GLS method was then attempted. This effort yielded a less problematic unidimensional solution; however excessive error variances were obtained for scale items two, 12, and 13. Given the extensive evidence of the external validity of the CETSCALE and the likely cause of the problem, the error variances for the three observed variables were reset to 0.005 , and the analysis was re-run.

Table 3

Generalized Least Squares Solution

\begin{tabular}{|c|c|c|c|c|}
\hline \multirow[t]{2}{*}{ Statistic } & \multicolumn{3}{|c|}{ Study } & \multirow[b]{2}{*}{$\begin{array}{l}\text { Netemeyer } \\
\text { et al. } 1991\end{array}$} \\
\hline & Fraering 2006 & $\begin{array}{l}\text { Yoo \& } \\
\text { Donthu } 2005\end{array}$ & $\begin{array}{l}\text { Durvasula } \\
\text { et al. } 1997\end{array}$ & \\
\hline \multicolumn{5}{|c|}{ Dimensionality } \\
\hline Chi-Sq/df Ratio & 4.869 & N/A & 3.69 & 1.77 \\
\hline GFI & 0.740 & 0.75 & 0.70 & N/A \\
\hline AGFI & 0.674 & N/A & 0.62 & N/A \\
\hline CFI & 0.000 & 0.93 & 0.86 & N/A \\
\hline \multicolumn{5}{|c|}{ Internal Consistency } \\
\hline Cronbach's Alpha & 0.94 & 0.96 & N/A & 0.95 \\
\hline Composite Reliability & 0.96 & N/A & 0.97 & 0.95 \\
\hline Variance Extracted & 0.60 & N/A & 0.64 & 0.55 \\
\hline
\end{tabular}

The results are better than expected, and are comparable with prior research conducted in the United States (Durvasula, Andrews, and Netemeyer 1997; Netemeyer, Durvasula, and Lichtenstein 1991; Yoo and Donthu 2005). Although the chi-square/degrees of freedom ratio is considerably higher than prior research (Durvasula, Andrews, and Netemeyer 1997; Netemeyer, Durvasula, and Lichtenstein 1991), it is within the bounds specified by Marsh and Hocevar (1985). Results for goodness of fit (GFI) and adjusted goodness of fit (AGFI) are comparable with prior efforts, but the comparative fit index (CFI) in this research is unacceptable. Internal consistency is relatively good, with both Composite Reliability and Variance Extracted well within the range of earlier work (Durvasula, Andrews, and Netemeyer 1997; Netemeyer, Durvasula, and Lichtenstein 1991). Thus additional confirmatory factor analysis was required.

Due to considerable empirical support for analysis of non-normal data (Bentler 1983; Browne 1982; Browne 1984; Muthen 1989; Sharma, Durvasula, and Dillon 1989), it was determined that the ADF method was the next logical step in confirmatory factor analysis. The results were substantially better than those obtained from the ML and GLS methods, with improvement in all four of the fit statistics. There was a slight decline in Composite Reliability, which was virtually the same as Cronbach's alpha (0.94). And Variance Extracted declined to 0.45, a level minimally below the level recommended by Hair and his colleagues (1995). However three of the four fit statistics are more favorable than those reported by Durvasula and his colleagues (1997). Thus the ADF method resulted in better model fit than the ML and GLS estimation techniques, indicating that the former approach remains a robust means of confirmatory factor analysis of non-normally distributed data. 


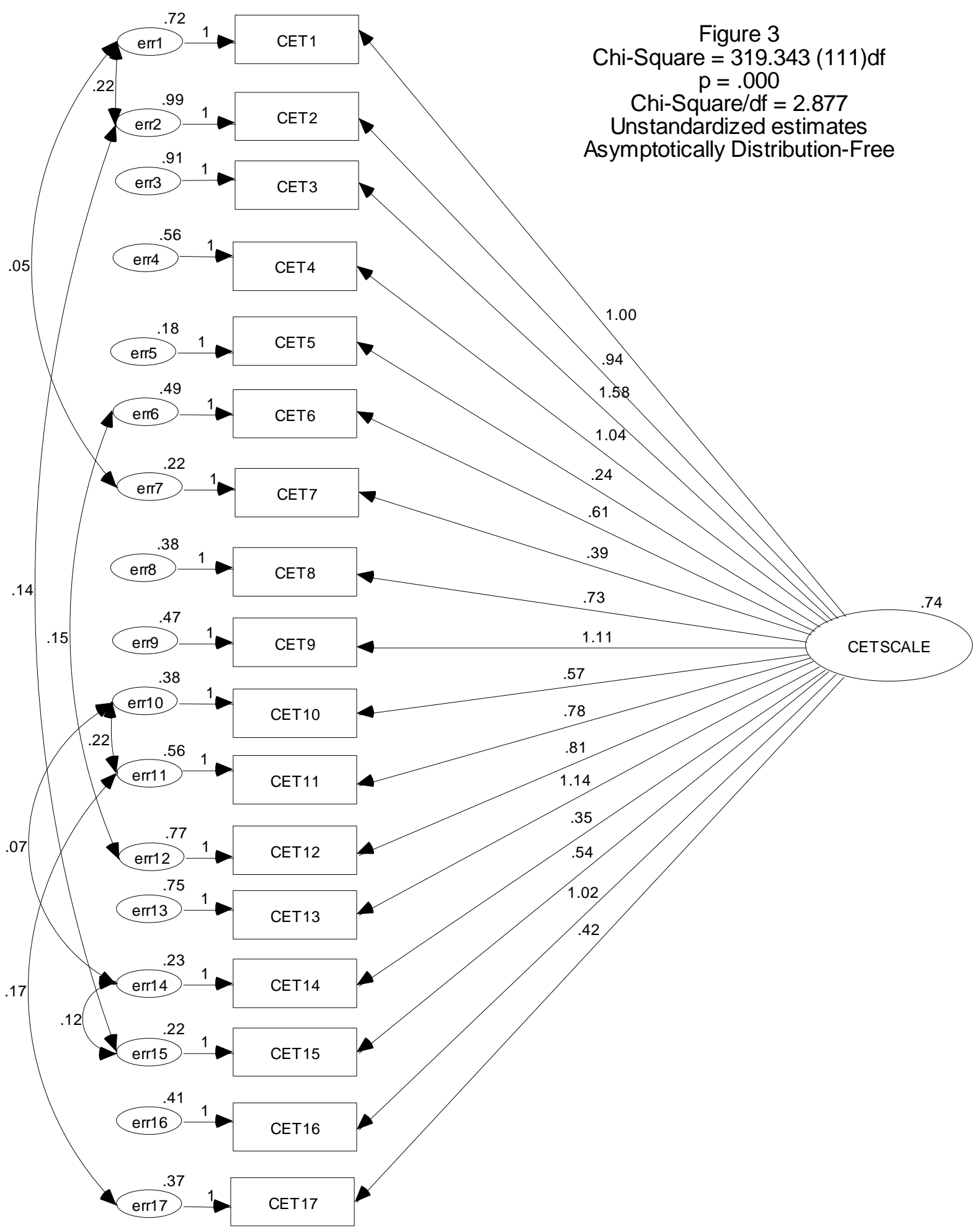


Table 4

Asymptotically-Free Distribution Solution

\begin{tabular}{lcccc}
\hline Statistic & \multicolumn{2}{c}{ Study } \\
\hline & Fraering 2006 & $\begin{array}{c}\text { Yoo \& } \\
\text { Donthu 2005 }\end{array}$ & $\begin{array}{c}\text { Durvasula } \\
\text { et al. 1997 }\end{array}$ & $\begin{array}{c}\text { Netemeyer } \\
\text { et al. 1991 }\end{array}$ \\
& & & \\
Chi-Sq/df Ratio & 2.877 & Dimensionality & 1.77 \\
GFI & 0.870 & N/A & 3.69 & N/A \\
AGFI & 0.821 & N/A & 0.70 & N/A \\
CFI & 0.779 & 0.93 & 0.62 & \\
& & & 0.86 & 0.95 \\
Cronbach's Alpha & 0.94 & Internal Consistency & N/A & 0.95 \\
Composite Reliability & 0.93 & 0.96 & 0.97 & 0.55 \\
Variance Extracted & 0.45 & N/A & 0.64 &
\end{tabular}

\section{RESULTS}

$\mathrm{H}_{1}$ asserts that college students are less biased against the purchase of foreign-made goods in 2005 than in 2000. Research conducted to date has been an almost uninterrupted downward trend in the ethnocentric attitudes of consumers, from a mean score of 68.58 (Detroit sample, Shimp and Sharma 1987) to 50.24 (Durvasula, Andrews, and Netemeyer 1997), 61.5 (Hult, Keillor, and Lafferty 1999), 45.2 (Fraering and Elahee 2001), and 43.87 (Yoo and Donthu 2005). In this research the 2005-6 survey of Business Administration undergraduates resulted in a mean CETSCALE score of 43.2, a decrease of two points from the survey taken in 2000. To correct the positive skew of the summated CETSCALE scores the data was transformed by taking the natural logarithm of the summated scale (Hair et al. 1995). An analysis of variance test indicates that the difference in the means of the two studies is not significant at $p=0.05$. Thus $\mathrm{H}_{1}$ is not supported.

CETSCALE reliability has been assessed using both Cronbach's Alpha and Composite Reliability. The two measures are very similar (Fornell and Larker 1981), but are subject to minor variation. For instance, Periera and his colleagues (2002) reported Cronbach's Alpha for surveys in Taiwan, India, and China of 0.89, 0.92, and 0.88, respectively, and Composite Reliability of $0.912,0.905$, and 0.90. But at least one research effort (Netemeyer, Durvasula, and Lichtenstein 1991) obtained identical Cronbach's Alpha and Composite Reliability statistics for the United States (0.95), France (0.92), Japan (0.91), and West Germany (0.94). Consistent with the CETSCALE literature $\mathrm{H}_{2 \mathrm{a}}$ anticipates that the reliability of the structural equation model in this research as measured by Cronbach's Alpha will be excellent (greater than 0.90, per Nunnally 1978). In this research Cronbach's Alpha is calculated by SPSS Release 11.5.0 was 0.94: Thus $\mathrm{H}_{2 \mathrm{a}}$ was supported. $\mathrm{H}_{2 \mathrm{~b}}$ asserts that Composite Reliability will be 0.90 or higher. Unlike Cronbach's Alpha, Composite Reliability varies according to the estimation method employed (i.e., Asymptotically Distribution-Free versus Generalized Least Squares) and model fit (i.e., GFI, AGFI, CFI, etc.). In this research the Composite Reliability of the Asymptotically Distribution-Free solution is 0.93 . Thus $\mathrm{H}_{2 b}$ is supported. Finally, $\mathrm{H}_{3}$ posits that Variance Extracted will be greater than $0.50 . \mathrm{H}_{3}$ is not supported as the statistic is 0.45. Prior efforts that have reported similar results include Netemeyer, Durvasula, and Lichtenstein (1991), who obtained values of 0.43 for France, 0.41 for Japan, and 0.49 for Germany, and Hult and his colleagues (1999), who obtained values of 0.47 for Japan and .485 for Sweden.

\section{SUMMARY FOR MANAGEMENT}

As the trend in the ethnocentric attitudes of young US consumers continues to decline the opportunities for firms with a global focus seeking to conduct business in this country multiply. The results of this research indicate that we are willing to make purchase decisions based on considerations such as fit and finish, style, and quality, irrespective of where the product is made. Consumers may also realize that many complex products are made of parts 
that are sourced from many countries, and assembled in yet another country. They are less likely to equate the purchase of American goods with patriotism, or equate the purchase of foreign goods with a decrease in the number of assembly-line jobs in the United States.

Only one scale item provides evidence of an ethnocentric tendency among Business Administration students: "Buy American-made products: Keep America working." This indicates that manufacturers of American-made goods should promote their products by boasting their home-country origin. Foreign firms that manufacture products in the United States should emphasize the number of component parts they use that are made in the United States, as well as the number of Americans they and their suppliers employ and the number of charitable causes that they support. American firms that repair and maintain equipment such as automobiles, trucks, and marine engines should emphasize the scope and depth of their expertise in keeping their customers' equipment in excellent operating condition. The remainder of the results indicates that firms have a great deal of latitude in promoting products on the basis of quality of their design, components, and manufacture. Thus in a flat world (Friedman 2005) US consumers are expected to become more discerning and discriminating in their purchase decisions.

\section{STUDY LIMITATIONS}

This research is the first to conduct a longitudinal analysis of CETSCALE scores. It does so with two homogeneous samples surveyed approximately six years apart (2000 and 2005-6). Use of two groups of similar respondents enhances the accuracy of the study by minimizing chance errors that could result from surveying an older or otherwise dissimilar group of people. Thus this research does not consider the ethnocentric attitudes of students in other academic programs. In doing so the attitudes of these other groups of people and the information they might provide are foregone. Another important limitation in this research was that no attempt was made to contact the respondents of the 2000 survey to obtain new CETSCALE data from them. During the years between the two surveys two incidents have occurred that had the potential to profoundly affect the way we view the world: The terrorist attacks of September 11, 2001, and concerns that illegal immigration has negative implications for the United States. In spite of these events the mean CETSCALE score of the 2005-6 survey is 43.21, inferring that the responses of survey participants tend to be twos and threes (the midpoint of the scale is four). Thus young adults in Business Administration programs continue to be fairly receptive toward purchasing foreign-made products. But because the cohort was not surveyed, information from them means that the changes in ethnocentric attitudes that have occurred in the intervening six years are not known.

\section{SUGGESTIONS FOR FUTURE RESEARCH}

What is the future of CETSCALE research? It has been 22 years since the first study was published (Shimp 1984). The measurement scale has been administered in countries around the world with varying degrees of success. While it might be interesting to follow the evolution of the ethnocentric attitudes of a heterogeneous cohort throughout its adult years, the knowledge that might be gained may not be commensurate with the effort expended by both respondents and scholars. Scholars should take note of the difficulties encountered in this research with non-normal data. These problems can be expected to continue in the future, and are likely to become even more positively skewed as consumers become more receptive to foreign-made products, as well as complex products with components sourced from around the world. The country of origin of such goods can be almost impossible to discern, and it is likely that the number of products of this type will increase in the future. Thus it may be time to evolve beyond to the CETSCALE to a more relevant measurement scale that addresses the positive and negative attitudes of consumers toward globalization.

\section{ENDNOTE}

${ }^{1}$ Cohort studies measure changes in groups over time. Usually the specific groups of people are different in each subsequent survey. 


\section{REFERENCES}

1. Alden, E., Doubt Over Bush Focus on Border Security force, Financial Times, May 17, 2006, p. 4.

2. Alden, E. and Johnson, J., El Boicot Set to Test Employers in US, Financial Times, May 1, 2006, p. 4.

3. Arbuckle, J. and Wothke, W., Amos 4.0 User's Guide, SmallWaters Corporation, Chicago, IL, 1999.

4. Babbie, E. and Wagenaar, T., Practicing Social Research, Wadsworth, Belmont, California, 1992.

5. Bai, J., Testing Parametric Conditional Distributions of Dynamic Models, Review of Economics and Statistics, Vol. 85, pp. 531-549, 2003.

6. Bailey, W. and Gutierrez de Pineres, S., Country of Origin Attitudes in Mexico: The Malinchismo Effect, Journal of International Consumer Marketing, Vol. 9, pp., 1997.

7. Bawa, A., Consumer Ethnocentrism: CETSCALE Validation and Measurement of Extent, Vikalpa, Vol. 29, pp. 43-57, 2004.

8. Bentler, P., Some Contributions to Efficient Statistics for Structural Models: Specification and Estimation of Moment Structures, Psychometrika, Vol. 48, pp. 493-517, 1983.

9. Browne, M., Covariance Structures, in Topics in Applied Multivariate Analysis (D. Hawkins, ed.), Cambridge University Press, Cambridge, England, 1982.

10. Browne, M., Asymptotically Distribution-Free Methods for the Analysis of Covariance Structures, British Journal of Mathematical and Statistical Psychology, Vol. 37, pp. 62-83, 1984.

11. Chan, W., Yung, Y., and Bentler, P., A Note on Using an Unbiased Weight Matrix in the ADF Test Statistic, Multivariate Behavioral Research, Vol. 30, pp. 453-459, 1995.

12. Durvasula, S., Andrews, J., and Netemeyer, R., A Cross-Cultural Comparison of Consumer Ethnocentrism in the United States and Russia, Journal of International Consumer Marketing, Vol. 9, pp. 73-93., 1997.

13. Fornell, C. and Larker, D., Evaluating Structural Equation Models with Unobservable Variables and Measurement Error, Journal of Marketing Research, Vol. 18, 39-50, 1981.

14. Fouladi, R., Performance of Modified Test Statistics in Covariance and Correlation Structure Analysis Under Conditions of Multivariate Nonnormality, Structural Equation Modeling, Vol. 7, pp. 356-410, 2000.

15. Fraering, M. and Elahee, M., Mexican and Mexican-American Ethnocentric Beliefs: A Cross-Cultural Application of the CETSCALE, Applied Business Research Conference Program and Proceedings, Article Number 287, 2001.

16. Friedman, T., The World is Flat: A Brief History of the Twenty-First Century, Farrar, Straus, and Giroux, New York, NY, 2005.

17. Hair, J., Anderson, R., Tatham, R., and Black, W., Multivariate Data Analysis, Prentice-Hall, Inc., Englewood Cliffs, NJ, 1995.

18. Herche, J., A Note on the Predictive Validity of the CETSCALE, Journal of the Academy of Marketing Science, Vol. 20, pp. 261-264, 1992.

19. Hult, G., Keillor, B., and Lafferty, B., A Cross-National Assessment of Social Desirability Bias and Consumer Ethnocentrism, Journal of Global Marketing, Vol. 12, pp. 29-43, 1999.

20. Johnson, J., Democracy Summer to Call for Immigration Reform, Financial Times, May 11, 2006, p. 3.

21. Kayak, E. and Kara, A., Consumer Perceptions of Foreign Products: An Analysis of Product-Country Images and Ethnocentrism, European Journal of Marketing, Vol. 36, pp. 928-949, 2002.

22. Kirchgaessner, S., Alden, E., Yeager, H., and Sevastopol, D., DP World Gives Up Control of US Ports, Financial Times, March 10, 2006, p. 1.

23. Lindquist, J., Vida, I., Plank, R., and Fairhurst, A., The Modified CETSCALE: Validity Tests in the Czech Republic, Hungary, and Poland, International Business Review, Vol. 10, pp. 505-516, 2001.

24. Luque-Martinez, T., Ibanez-Zapata, J., and Barrio-Garcia, S., Consumer Ethnocentrism Measurement: An Assessment of the Reliability and Validity of the CETSCALE in Spain, European Journal of Marketing, Vol. 34, pp. 1353-1373, 2000.

25. Marsh, H. and Hocevar, D., Application of Confirmatory Factor Analysis to the Study of Self-Concept: Firstand Higher-Order Factor Models and Their Invariance Across Groups, Psychological Bulletin, Vol. 97, pp. 562-582, 1985.

26. Muthen, B., Multiple-Group Structural Modeling with Non-Normal Continuous Variables, British Journal of Mathematical and Statistical Psychology, Vol. 42, pp. 55-62, 1989. 
27. Netemeyer, R., Durvasula, S., and Lichtenstein, D., A Cross-National Assessment of the Reliability and Validity of the CETSCALE, Journal of Marketing Research, 28, pp. 320-327, 1991.

28. Nielsen, J. and Spence, M., A Test of the Stability of the CETSCALE, A Measure of Consumers' Ethnocentric Tendencies, Journal of Marketing Theory and Practice, Vol. 5, pp. 68-76, 1997.

29. Nunnally, J., Psychometric Theory, McGraw-Hill, New York, NY, 1978.

30. Olsson, U., Foss, T., Troye, S., and Howell, R., The Performance of ML, GLS, and WLS Estimation in Structural Equation Modeling Under Conditions of Misspecification and Nonnormality, Structural Equation Modeling, Vol. 7, pp. 557-595, 2000.

31. Pereira, A., Hsu, C., and Kundu, S., A Cross-Cultural Analysis of Ethnocentrism in China, India, and Taiwan, Journal of International Consumer Marketing, Vol. 15, pp. 77-90, 2002.

32. Reardon, J., Miller, C., Vida, I., and Kim, I., The Effects of Ethnocentrism and Economic Development on the formation of Brand and Ad Attitudes in Transitional Economies, European Journal of Marketing, Vol. 39, 737-754, 2005.

33. Sharma, S., Durvasula, S., and Dillon, W., Some Results on the Behavior of Alternate Covariance Structure Estimation Procedures in the Presence of Non-Normal Data, Journal of Marketing Research, Vol. 26, pp. 214-21, 1989.

34. Sharma, S., Shimp, T., and Shin, Consumer Ethnocentrism: A Test of Antecedents and Moderators, Journal of the Academy of Marketing Sciences, Vol. 23, pp. 26-37, 1995.

35. Shimp, T., Consumer Ethnocentrism: The Concept and a Preliminary Empirical Test, Advances in Consumer Research, Vol. 11, pp. 285-290, 1984.

36. Shimp, T. and Sharma, S., Consumer Ethnocentrism: Construction and Validation of the CETSCALE, Journal of Marketing Research, Vol. 24, pp.280-289, 1987.

37. Shoham, A. and Brencic, M., Consumer Ethnocentrism, Attitudes, and Purchase Behavior: An Israeli Study, Journal of International Consumer Marketing, Vol. 15, pp. 67-86, 2003.

38. Swann, C. and Alden, E., The Americas: US Trade Deficit Widens to Record \$68.5bn, Financial Times, March 10, 2006, page 5.

39. Vida, I. and Fairhurst, A., Factors Underlying the Phenomenon of Consumer Ethnocentricity: Evidence from Four Central European Countries, International Review of Retail, Distribution and Consumer Research, Vol. 9, pp. 321-337, 1999.

40. Watson, J. and Wright, K., Consumer Ethnocentrism and Attitudes Toward Domestic and Foreign Products, European Journal of Marketing, Vol. 34, pp. 1149-1166, 2000.

41. Yoo, B. and Donthu, N., The Effect of Personal Cultural Orientation on Consumer Ethnocentrism: Evaluations and Behaviors of U.S. Consumers Toward Japanese Products, Journal of International Consumer Marketing, Vol. 18, pp. 7-44, 2005.

42. Zheng, B., Formby, J., Smith, W., and Chow, V., Inequality Orderings, Normalized Stochastic Dominance, and Statistical Inference, Journal of Business and Economic Statistics, Vol. 18, pp. 479-488, 2000. 

NOTES 